\title{
Die Redtipred)utug in
}

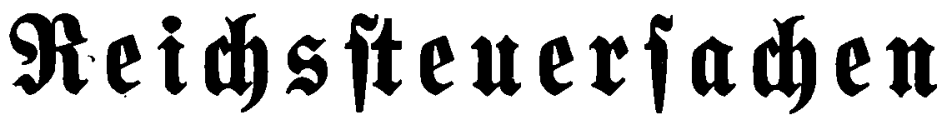

\author{
Sgerausgegeben von
}

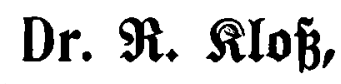

Reidjefinauzrat in Mündjen.

\section{Band 1920}

euthaltend bie zurïfliegenden $\mathfrak{a}$ hre bis mit 1919.

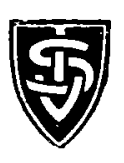

1920

Mïndyen, Berlin und Leipzitg

I. S中)eiber Berlag (arthur Sellier). 


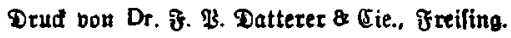

